ISSN 2450-6869

Volume 1, No. 9, 2020

\section{DEFENCE SCIENCE REVIEW}

\author{
www.defencesciencereview.com.pl
}

DOI: $10.37055 / \mathrm{pno} / 130386$

\title{
CHALLENGES RELATED TO UNMANNED AERIAL VEHICLES
}

\section{Original article}

Accepted: September 2020

Published: November 2020

Peer review:

Double blind

Keywords:

UAV, NBR, UAVO, VLOS and BVLOS, DRONE

This work is licensed under the Creative Commons AttributionNonCommercial-NoDerivatives 4.0 License

\author{
Marek Tomaszycki ${ }^{1}$ \\ ORCID - 0000-0001-7952-0954 \\ Military University of Land Forces in Wrocław \\ ul. Piotra Czajkowskiego 109, 51-147 Wrocław
}

Jacek Krawczyk ${ }^{2}$

ORCID - 0000-0001-6116-7099

Helena Chodkowska University of Technology and Economics in Warsaw

ul. Jagiellońska 82f, 03-301 Warszawa

\begin{abstract}
The Regulation of the European Parliament and of the Council (EC) No. 2018/1139 (known as NBR - New Basic Regulation) on common rules in the field of civil aviation was introduced in order to regulate the issue of UAVs Unmanned Aerial Vehicles, in all weight categories. It represents a new regulatory approach, which is of major importance in the field of European aviation legislation. Until the new regulation came into force, UAVs with a maximum take-off weight (MTOM) below $150 \mathrm{~kg}$ were subject to the regulations of authorities of individual EU Member States. The NBR introduced by implementing acts in the field of UAV forces the national aviation authorities of states to change the regulations currently in force. The most important issues that need to be standardised include the requirement to enter UAVs with the MTOW equal to or lower than $25 \mathrm{~kg}$ in the aircraft
\end{abstract}

\begin{abstract}
${ }^{1}$ Lt Gen (Ret.) Marek Tomaszycki holds a Ph.D. in social sciences (specialisation in defence sciences) and currently works at the Military University of Land Forces in Wrocław at the Faculty of Management. Marek Tomaszycki participated in two missions: in Iraq 2003-2004 (where he conducted training for the security forces of Iraq) and in Afghanistan 2007 (where he served as contingent commander). His main areas of research include: defence policy, leadership and command, humanitarian law of armed conflicts and crisis management. $\mathrm{He}$ is the author and co-author of many departmental studies, expert opinions and scientific publications.

${ }^{2}$ Jacek Krawczyk, Ph.D., Eng., served in the air force, where he was mainly involved in air traffic management and UAVs. Currently, he works as a lecturer at Helena Chodkowska University of Technology and Economics in Warsaw, where he also serves as Head of Aviation Education. Interests: Air transport, UAV (opportunities, innovations, new technologies, challenges and expectations), security in the airspace, air traffic management, threats to NATO, oversea civil and state aviation flights.
\end{abstract}


register, granting the BVLOS (Beyond Visual Line of Sight) fight approval and the UAVO (Unmanned Aerial Vehicle Operator) certification process. In the author's opinion, what may be difficult and dangerous for safety in the airspace is the transitional period. During that time, manufacturers, airspace users and ATS (Air Traffic Service) will have to perform their tasks keeping in mind that it is a period when the new legal regulations currently prepared for entry into force will affect the entire sector related to unmanned aviation, which will also have an impact on manned aviation. Purpose: The purpose of the article is to discuss the basic challenges posed by the currently developed technology of unmanned aerial vehicles. Method: The scientific methods used in the paper include analysis, criticism of the literature on the subject and logical construction. Results: The article shows the differences between the existing regulations and those proposed by the European Commission and EASA (European Union Aviation Safety Agency). In addition, it presents the process of granting the approval to perform air operations by manned aircraft. 


\section{New regulations in the field of aviation safety}

The European Commission has announced the entry into force of Regulation 2018/1139 of the European Parliament and of the Council on common rules in the field of civil aviation and establishing a European Union Aviation Safety Agency, and repealing Regulation (EC) No 211/2005, (EC) No 1008/2008, (EU) No 996/2010, (EU) No 376/2014 of the European Parliament and of the Council, Directive 214/30/EU and 2014/53/EU of the European Parliament and of the Council, as well as repealing Regulation (EC) 552/2014 and (EC) 216/2008 of the European Parliament and of the Council and Council Regulation (EEC) No 3922/91.

The above-mentioned new regulatory approach constitutes an important change in the European legislation on aviation. Currently, UAVs with a Maximum Take-off Weight (MTOW - Maximum Take-off Weight or MTOM - Maximum Take-off Mass, including fuel, batteries, payload etc.) below $150 \mathrm{~kg}$ are subject to regulations by the authorities of individual EU Member States. The new regulation covers the entire UAV weight category (COMMISSION DELEGATED REGULATION (EU) 2019/945 of 12 March 2019 on unmanned aircraft systems and on third-country operators of unmanned aircraft systems, Art. 3 point 1. Unmanned Aerial Vehicles are defined as any aircraft operated or intended to be operated without a pilot on board that can be guided autonomously or by remote control. Including all UAVs into one regulatory system will help tp resolve the difficulties related to different UAV airworthiness and UAV-related operational rules in individual EU Member States. It will also lead to the harmonization and significant acceleration of further actions taken by the EU and EASA in the field of UAVs.

One of the goals of the introduction of the NBR (New Basic Regulation) is the standardisation of regulations on the use of drones (DRONE - Dynamic Remove Operation Navigation Equipment) in all European Union countries. For the first time, this issue will be regulated at the supranational level for all UAV classes. The new, standardised regulations will allow UAVO (Unmanned Aerial Vehicle Operator) to perform flight operations outside the country in which they obtained the unmanned aircraft operational authorisation.

The NBR has is of a general nature and does not contain detailed provisions on the operation of unmanned aerial vehicles. The classification of UAVs was made primarily on the basis of a flight risk analysis. Flight risk, in turn, is calculated taking into account the weight of a given drone, its speed, generated noise and equipment on board. 
The most important change that will take place once the NBR becomes effective is the obligation to register and certify drones. The details are described in the delegated and implementing regulations, which set out the rules for UAV operation, certification, registration, as well as operator training.

The content of the legal acts related to the NBR was announced by the European Commission and representatives of the EU and EASA member states. The application of the NBR to state UAVs is limited and excludes the use of such vehicles in warfare and operations conducted in order to protect the security of the state and the citizens. The provisions of the NBR do not apply to aircraft, their engines, propellers, parts, non-installed equipment and equipment to control aircraft remotely, while carrying out military, customs, police, search and rescue, firefighting, border control, coastguard or similar activities or services under the control and responsibility of a Member State, undertaken in the public interest by or on behalf of a body vested with the powers of a public authority.

Detailed provisions are contained in the following two regulations:

- Commission Delegated Regulation (EU) No 2019/945 of March 12, 2019 on unmanned aerial vehicle systems and unmanned aerial vehicle operators from third countries,

- European Commission Implementing Regulation (EU) No 2019/947 of May 24, 2019 on the rules and procedures for the operation of unmanned aircraft.

The greatest change in terms of the new EU regulations will be the classification of operations. The European Commission and EASA have established the following three categories for UAV air operations:

1) Open

The open category will comprise five subcategories (marked with symbols from $\mathrm{C} 0$ to C4). Classification to a specific subcategory will depend on the weight of a given drone, its speed, maximum flight altitude, safety technologies used (e.g. follow-me, geo-awareness, e-ID), voltage, level of generated noise, lighting equipment for day or night flights, as well as its physical appearance (such as any sharp edges present). The types of approved operations will be assigned to each subcategory of the vehicles. Flying over crowds of people will be prohibited, regardless of the mass of the drone. In addition, the implementing regulations will be more restrictive regarding compulsory theoretical and practical training.

Classification:

$\mathrm{CO}-\mathrm{MTOW}$ including payload below $250 \mathrm{~g}$, 
$\checkmark$ C1 - MTOW including payload below $900 \mathrm{~g}$,

$\checkmark$ C2 - MTOW including payload below $4 \mathrm{~kg}$,

$\checkmark$ C3-MTOW including payload below $25 \mathrm{~kg}$, the maximum dimensions below $3 \mathrm{~m}$,

$\checkmark$ C4-MTOW including payload above $25 \mathrm{~kg}$.

For this category, VLOS (Visual Line of Sight) operations up to the height of 120 AGL (Above Ground Level) will be allowed.

While performing air operations with a UAV, the operator is obliged to ensure constant safe flight control, stability and maneuverability as well as uninterrupted data transmission, which guarantees the efficiency of control and maneuverability of the UAV in all circumstances, according to operational needs and air traffic situation.

In addition, the appropriate mechanical strength of the UAV must be ensured in terms of its construction, materials used and proper operation, which guarantees high reliability, the safety of the UAVO and other people who are in the vicinity of air operations, as well as air traffic security for other airspace users.

For the above-mentioned categories, the manufacturer will be responsible for preparation of the technical documentation and will take all necessary measures to ensure compliance of the products with the technical documentation during the production process and operation of the vehicle.

Modules B and C (Decision No 768/2008/EC of the European Parliament and of the Council) are used to verify conformity and include EC type tests and conformity to type tests based on internal production control in accordance with Annex II to Decision 768/2008/EC. The conformity to type test is carried out by a notified body which prepares a conformity assessment report.

Conformity assessment is performed by notified bodies in order to demonstrate the compliance of a given UAS (Unmanned Aerial System, which includes UAV and GCA (Ground Control Station)) with regulations from the stage of their production. Notified bodies are designated by each Member State. They need to be independent and cannot be governmental entities.

2) Specific

This category includes UAVs with a dimension of at least $3 \mathrm{~m}$ or where flight operations are performed using specialized aircraft using flight scenarios previously defined and approved by air traffic supervisory body. Such air operations can be 
performed according to VLOS and BVLOS (Visual Line of Sight and Beyond Visual Line of Sight) procedures.

3) Certified

This category includes UAVs with dimensions exceeding $3 \mathrm{~m}$ intended for operation over crowds of people, for the transport of people or designed for the transport of dangerous goods, with risk analysis taken into account. Non-certified UAVs are prohibited for operation for the above-mentioned purposes. Certification is carried out for design, production and maintenance processes (EU 748/212, 640/215, 1321/2014). Air operations can be performed according to VLOS and BVLOS procedures.

The vehicles will be subject to technical specification in order to verify the product's conformity with harmonised standards adopted in accordance with Regulation (EU) No. 1025/2012 of the European Parliament and of the Council.

National public authorities of EU member states are required to identify competent notified bodies for assessment of product conformity in accordance with the relevant requirements. What is important is to ensure a consistent level of conformity. For this reason it is necessary to establish requirements not only for notified bodies, but also for entities involved in the process of assessment, notification and monitoring of notified bodies.

Requirements set out for notified bodies:

- they must be established so as to avoid any conflicts in the conformity assessment process;

- they must be organised in a way that guarantees objectivity and impartiality; they must be organised in such a way as to ensure that the decision related to notification of a body conducting conformity assessment is represented by competent persons different from those who conducted the assessment,

- they must treat the information received as confidential,

- they must employ a sufficient number of competent staff to perform their tasks properly.

In order to ensure competitiveness, equal treatment of economic entities as well as in order to avoid unnecessary burden on administrative economic entities, notified bodies should cooperate with one another and coordinate the processes of issuing decisions regarding conformity.

The entities concerned should have the right to appeal against conformity assessments issued by notified bodies. The appeal procedure should be transparent and feasible for implementation. 
An important issue is UAS technical documentation. In order to ensure appropriate production, service, maintenance and safe use of the system, it should be stored by the manufacturer for 10 years from placing the product on the market. Technical documentation may also be reviewed in the event of accidents, plane crashes, etc. Test results in the natural and laboratory environment may be of key importance in explaining the causes that led to the above-mentioned adverse events.

\section{National regulations in the field of aviation safety}

Within the territory of the Republic of Poland, it is prohibited to use aircraft that do not have a valid airworthiness certificate, flight permit for special category aircraft (Helnarska, Krawczyk, Korytek, 2018), hereinafter "special flight permit" or any other equivalent document, or that do not meet the conditions specified in the type certificate, a supplemental type-certificate, flight permit or other equivalent document ${ }^{3}$.

Airworthiness of aircraft and their engines, propellers, parts and accessories is verified by EASA in the course of their design, production and operation to the extent and on the terms specified in Regulation No 216/2008/EC, Regulation No 1702/2003/EC and Commission Regulation (EC) No 2042/2003 of 20 November 2003 on the continuing airworthiness of aircraft and aeronautical products, parts and appliances, as well as on approvals for organisations and personnel involved in these tasks (OJ L EC 315 of 28.11.2003, p. 1, Polish special edition, chapter 7, vol. 7, p. 541). Within the scope not reserved for EASA, the President of the Civil Aviation Authority shall assesses and verify airworthiness of aircraft and their engines, propellers, parts and accessories in the course of their design, production and operation, taking into account the requirements of Regulation No 216/2008/EC, Regulation No 1702/2003/EC and Regulation 2042/2003/EC.

The decisions on airworthiness directives ${ }^{4}$ not subject to EASA supervision, shall be issued by way of an administrative decision, in accordance with the requirements of Annex 8 to the Convention referred to in Art. 3 resolutions of international organizations in the field of civil aviation binding on the Republic of Poland, sec. 2, airworthiness directives setting out the obligations for aircraft users and owners with regard to their continuing airworthiness.

\footnotetext{
${ }^{3}$ Journal of Laws 2018. Item 1183 - The Act of July 3, 2002 - Aviation Law, Chapter 3. Airworthiness of aircraftArt. 45. Airworthiness.

${ }^{4}$ Journal of Laws 2018. Item 1183 - The Act of July 3, 2002 - Aviation Law, Chapter 3. Airworthiness of aircraft Art. 47. Decisions on airworthiness directives.
} 
The President of the Civil Aviation Authority (CAA) declares the conformity ${ }^{5}$ of aircraft parts and accessories not subject to EASA supervision based on the relevant provisions of law in the field of aircraft continuing airworthiness by issuing a certificate of airworthiness. The certificate is issued at the request of an entity who presents the type design and documentation that proves compliance with the relevant legal provisions in the field of continuing airworthiness of the aircraft. It can be valid for an indefinite period of time. In a certificate of approval, the President of the CAA specifies the conditions for the use of aircraft parts and accessories, as well as the restrictions imposed due to flight safety. The President of the CAA may refuse to issue a certificate of approval in the event the aircraft parts and accessories do not meet the legal requirements in the field of continuing airworthiness.

The President of the CAA may suspend a certificate of approval for a specified period of time, if the aircraft parts and accessories no longer meet the legal requirements in the field of continuing airworthiness. Such a certificate may also be revoked if during the period of its suspension, compliance with the legal provisions on continuing airworthiness has not been restored.

Within the scope not reserved for EASA, the President of the CAA confirms the compliance of the technical condition of the aircraft ${ }^{6}$ entered into the aircraft register with the requirements specified in the type-certificate and the legal provisions in the field of continuing airworthiness by issuing a certificate of airworthiness. Such a certificate is issued with safety considerations in mind for a limited period of time (up to 24 months), unless otherwise provided for in Regulation 1702/2003/EC. The President of the CAA may refuses to issue a certificate of airworthiness if the aircraft does not meet the requirements or suspends it for a specific period of time, if the aircraft no longer meets the requirements.

Certificates of airworthiness may be revoked by the President of the CAA if compliance with the requirements has not been restored during the period of their suspension. For aircraft intended for export, export certificate of airworthiness are issued. Issuing (or refusal to issue) certificates of airworthiness and export certificates of airworthiness, their renewal (or refusal to renew them), as well as their suspension and revocation shall be made by way of an administrative decision issued by the President of the CAA.

\footnotetext{
${ }^{5}$ Journal of Laws 2018. Item 1183 - The Act of July 3, 2002 - Aviation Law, Chapter 3. Airworthiness of aircraft Art. 48. Certificate of approval.

${ }^{6}$ Journal of Laws 2018. Item 1183 - The Act of July 3, 2002 - Aviation Law, Chapter 3. Airworthiness of aircraft Art. 49. Certificate of airworthiness.
} 
Within the scope not reserved for EASA, the President of the CAA may, by way of an administrative decision, may issue a flight approval for an aircraft without a valid certificate of airworthiness, flight permit or another equivalent document, or in conditions not provided for in these documents for the purposes of: conducting flight tests, test flights, export of the aircraft, transport of the aircraft for repair, and for other purposes related to airworthiness verification.

The operator, commander and other members of the aircraft crew are required to comply with ${ }^{7}$ the requirements and restrictions set out in the certificate of airworthiness, flight permit or other equivalent documents.

Type certificates and supplementary type certificates, issued by the President of the CAA for aircraft not covered by EASA supervision may be:

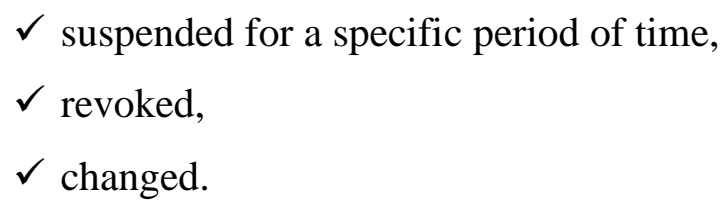

by the President of the CAA, by way of an administrative decision.

Airworthiness of aircraft is the prerequisite for ensuring the safety of air operations in the airspace designated for air traffic as well as in the airspace designated for conducting specific air operations. It is justified to make the rules for issuing flight permits equal for both civil and military users.

Civil and state aircraft are entered into the aircraft registers kept by the President of the $\mathrm{CAA}^{8}$, the Minister of National Defence ${ }^{9}$ and the Minister of the Interior $^{10}$. In order to ensure the safety of airspace users, it is justified to make the rules for entry into the above-mentioned registers equal for both civil and state users and aircraft.

An aircraft with flight permit issued by the aviation authorities of a given state may perform air operations in accordance with the requirements for the airspace of other states. Therefore, it is necessary that global organisations, such as ICAO, select the organisation responsible for the process of airworthiness certification (currently for the European airspace it is EASA) and ensure the same requirements for all aircraft manufacturers and users. In

\footnotetext{
7 Journal of Laws 2018. Item 1183 - The Act of July 3, 2002 - Aviation Law, Chapter 3. Airworthiness of aircraft Art. 51. Responsibilities of operators, commanders and aircraft crew members

${ }^{8}$ Journal of Laws 2018. Item 1183 - The Act of July 3, 2002 - Aviation Law, Chapter 2. Aircraft registers Art. 34 ,

${ }^{9}$ Journal of Laws 2018. Item 1183 - The Act of July 3, 2002 - Aviation Law, Chapter 2. Aircraft registers Art. 34 ,

${ }^{10}$ Journal of Laws 2018. Item 1183 - The Act of July 3, 2002 - Aviation Law, Chapter 2. Aircraft registers Art. 44 ,
} 
addition, the entry of an aircraft into the relevant aircraft register should be made in compliance with clearly stipulated standards and supervised by international aviation institutions (Kozuba, Krawczyk, Korytek, 2018).

This document should be the same for all types of aircraft, also for the certified category of UAVs, and be available for inspection by authorised persons at any time. Aircraft documentation should be kept both in paper and electronic forms throughout the useful life of the aircraft.

In order to ensure the proper level of safety in the airspace, the requirements imposed on UAVs at the stage of their design, testing, production, commissioning and certification must be the same for all entities that use them.

However, it should be emphasised that the UAVs intended for military use often perform air operations in difficult weather and operational conditions, at times at the upper limit of their material strength and data transmission capacity. For this reason, the technical requirements set out for such vehicles should be higher than for manned and unmanned civil aerial vehicles.

\section{Conclusions}

The NBR establishes the basic framework for functioning of the UAS. Detailed requirements are specified only for the open category. There are no detailed implementing acts for the special category, which covers UAVs performing air operations according to specific scenarios. Classification into the third, certified category can be made by competent state institutions. The certified category covers UAVs that are not permitted to perform air operations under the special category. The basis for granting permits to perform air operations in this category is a positive result of the risk assessment of the planned air operations.

The certified category has the same requirements as those set for manned aviation. The certification process is conducted for the unmanned aerial system as a whole (the unmanned aerial system covered by the certification complies with the relevant requirements of the Commission regulations (EU) 748/2012, 640/2015 and 1321/2014).

The NBR covers all the aspect related to UAVs, including their weight. According to the regulations previously in force, UAVs with the weight of up to $150 \mathrm{~kg}$ were exempt from the jurisdiction of EASA and were under the authority of the state in which they were registered. The competent aviation authorities or authorised entities are responsible for the assessment of conformity and verification of airworthiness of the vehicles, their engines, propellers, parts and appliances, in the course of the processes of design and testing. 
Aviation authorities responsible for legislative issues will have to adapt the Polish regulations on UAV/S to those introduced by the European Commission and EASA. According to national regulations, UAVs with an MTOW below $25 \mathrm{~kg}$ are subject to obligatory registration in the aircraft register. The NBR for this weight category, however, does not impose such a requirement.

Another point of difference is that the Polish legislation grants BVLOS flight approvals for UAVs lighter than $25 \mathrm{~kg}$. In turn, the implementing acts of the NBR do not provide for autonomous UAV flights lighter than $25 \mathrm{~kg}$.

The differences also concern the issues of UAVO certification. According to the NBR, the requirement for UAVO certification should be based on the kinetic energy generated by the UAV. It should also be required in the event of a threat to privacy, data protection or environmental security. National regulations do not provide for the requirement of UAVO certification according to such criteria.

The transitional period in terms of issuing certificates of airworthiness and conducting UAV certification may pose certain difficulties or even dangers. Therefore, close cooperation between the aviation authorities of individual states and EASA in terms of the introduction of the new regulations for unmanned aviation is desirable, and the safety of airspace users as well as the integration of manned and unmanned aviation in the common airspace should be given priority in this process. 


\section{References:}

Helnarska, K.J., Krawczyk, J. \& Korytek, Ł. (2018) 'The specificity of crossing air borders by civil and state aircraft', MATEC Web of Conferences 236, 01005 (2018), https://doi.org/10.1051/matecconf /201823601005, LOGI 2018.

Kozuba, J., Krawczyk, J., \& Korytek, Ł. (2018) 'The impact of air traffic increases on the safety of air operations in the Polish airspace', Scientific Journal of Silesian University of Technology, Series Transport, 98, pp. 53-63. DOI: https://doi.org/10.20858/sjsutst.2018.98.6.

\section{Other sources}

1. EASA standards (Officila Publication) - Certification Specifications for NormalCategory Aeroplanes (CS-23), earlier coded for JAR 23.

2. ICAO, Annex 2 Air Traffic Regulations, Wydanie dziesiąte, Lipiec 2005 r.

3. ICAO, Annex 8 Airworthiness Of Aircraft, Wydanie jedenaste, Lipiec 2010.

4. ICAO, Annex 11 Air Traffic Services. Wydanie ósme, Lipiec 2004 r.

5. International Civil Aviation Convention signed on 7 December 1944. (OJ of 26 June 1959).

6. Regulation of March 26, 2013, on the Exclusion of Some Provisions of the Aviation Law Act for Certain Types of Aircraft and Determining the Conditions and Requirements Relating to the Use of Such Aircraft, which sets out the rules for operation of UAS weighing less than $25 \mathrm{~kg}$ (Dz. U. z 2013 r. poz. 440).

7. Regulation of June 3, 2013, on Certificates of Competency applicable to the operators of UAS (Dz. U. z 2013 r. Nr 664).

8. Regulation of April 26, 2013, on the Technical and Operational Rules on Aircraft of Special Category, Not Subject to the Supervision of the European Aviation Safety Agency, which mostly applies to UAS weighing more than 25 (Dz. U. z 2013 r. Nr 524).

9. Regulation of August 8, 2016 amending the regulation on the Exclusion of Some Provisions of the Aviation Law Act for Certain Types of Aircraft and Determining the Conditions and Requirements Relating to the Use of Such Aircraft. (Dz. U. z 2016 r. Poz. 1317).

10. Rozporządzenia Parlamentu Europejskiego i Rady nr 2018/1139 w sprawie wspólnych zasad w dziedzinie lotnictwa cywilnego i utworzenia Agencji Bezpieczeństwa Lotniczego oraz zmieniające rozporządzenie Parlamentu 
Europejskiego i Rady (WE) nr 211/2005, (WE) nr 1008/2008, (UE) nr 996/2010, (UE) nr 376/2014, i dyrektywy Parlamentu Europejskiego i Rady Europejskiej nr 214/30 UE i 2014/53/UE, a także uchylające rozporządzenie Parlamentu Europejskiego i Rady (WE) 552/2014 i (WE) nr 216/2008 i Rozporządzenie Rady (EWG) nr 3922/91.

11. Rozporządzenie delegowane Komisji (UE) 2019/945 z dnia 12 marca 2019 r. w sprawie bezzałogowych systemów statków powietrznych oraz operatorów bezzałogowych systemów powietrznych z państw trzecich.

12. Rozporządzenie wykonawcze Komisji (UE) 2019/947 z dnia 24 maja 2019 r. w sprawie przepisów i procedur dotyczących eksploatacji bezzałogowych statków powietrznych.

13. Ustawa z dnia 3 lipca 2002 r. - Prawo lotnicze Dz.U.2018. Poz. 1183. 